\title{
Variation in Fatty Acid Contents of Milk and Milk Fat Within and Across Breeds
}

\author{
H. Soyeurt, ${ }^{\star} \dagger^{1}$ P. Dardenne, $\neq$ A. Gillon, ${ }^{\star}$ C. Croquet, ${ }^{\star} \S$ S. Vanderick, ${ }^{\star}$ P. Mayeres, ${ }^{\star} \rrbracket$ \\ C. Bertozzi, 凤 and N. Gengler*§ \\ *Gembloux Agricultural University, Animal Science Unit, B-5030 Gembloux, Belgium \\ †Fonds pour la Formation à la Recherche dans l'Industrie et l'Agriculture (FRIA), B-1000, Brussels, Belgium \\ $\ddagger$ Walloon Agricultural Research Center, Quality Department, B-5030 Gembloux, Belgium \\ $\S N a t i o n a l$ Fund for Scientific Research, B-1000 Brussels, Belgium \\ TWalloon Breeders Association, B-5530 Ciney, Belgium
}

\section{ABSTRACT}

The aim of this research was to study the potential for selection of cows with a higher nutritional quality of milk fat by studying the differences in fatty acid profiles within and across the following breeds: Dual Purpose Belgian Blue, Holstein-Friesian, Jersey, Montbeliarde, and non-Holstein Meuse-Rhine-Yssel type Red and White. Six hundred milk samples from 275 animals were taken from 7 herds. Several types of fatty acids in milk and milk fat were quantified using midinfrared spectrometry and previously obtained calibration equations. Statistical analyses were made using a mixed linear model with a random animal effect. The variance components were estimated by using REML. Results showed breed differences for the fatty acid profile. The repeatability estimate obtained in the present study may suggest the existence of moderate additive genetic variance for the fatty acid profile within each breed. Results also indicated variation for each analyzed milk component in the whole cow population studied. Genetic improvement of the nutritional quality of milk fat based on fatty acid profiles might be possible, and further research and development are warranted. Key words: milk quality, breed difference, fatty acid, fat

\section{INTRODUCTION}

Improving the nutritional quality of milk fat has been the topic of recent research. Feed supplementation, the most popular way to improve the nutritional quality of milk, presents certain disadvantages. First, this approach ignores the animal genetic effect, even though the effect of genetics on milk components such as milk fat has been demonstrated previously. Second, this im-

Received December 23, 2005.

Accepted July 4, 2006.

${ }^{1}$ Corresponding author: soyeurt.h@fsagx.ac.be provement is not permanent. Indeed, if supplementation is stopped, the additional nutritional quality disappears. The advantages of the genetic approach are linked to these disadvantages: Genetic improvement is permanent and has the advantage of creating additional value through selection.

Average cow milk fat contains $70 \%$ saturated fatty acids (SAT), 25\% monounsaturated fatty acids (MONO), and 5\% polyunsaturated fatty acids (POLY) (Grummer, 1991). A combination of milk lipids more favorable to human health would be around 30\% SAT (Pascal, 1996), 60\% MONO, and 10\% POLY (Hayes and Khosla, 1992). The fatty acid profile of cow's milk is therefore far from optimal. However, the observed variations in SAT, MONO, and POLY suggest that the milk fat composition can be modified by various means (e.g., feeding and genetics) to be brought closer to the optimal profile (Palmquist et al., 1993). Many results are available describing the influence of feeding (e.g., Demeyer and Doreau, 1999; Chilliard et al., 2000); however, many fewer are available on breed and individual genetic differences, even though variation in the overall milk fat among breeds is well known (e.g., Interbull, 2005). Also, not all the fatty acids in a specific class (SAT, MONO, or POLY) have the same effect on human health. In the case of SAT, although myristic acid is known for its negative effect on cardiovascular diseases, stearic acid does not seem to have this effect (Hu et al., 1999). Similarly, in POLY, the $n-6$ fatty acids appear to have negative effects on human health because of their overabundance in the Western diet. The current ratio of $n-6: n-3$ is estimated to be $15-20$ to 1 in the human Western diet (Simopoulos, 2003). It is therefore important to check the global fatty acid profile in milk if one wants to assess the nutritional quality of bovine milk fat.

An alternative way to study the nutritional quality of milk fat is to analyze the variations in $\Delta^{9}$-desaturase activity. This enzyme is important to the fatty acid composition in milk because it is responsible for the 
majority of MONO and the totality of conjugated linoleic acids (CLA) in milk. The $\Delta^{9}$-desaturase activity can be studied by analyzing the ratio of product to substrate (14:1 cis-9 to $14: 0,16: 1 \mathrm{cis}-9$ to $16: 0,18: 1 \mathrm{cis}-9$ to $18: 0$, and 18:1 trans-11 to CLA). Through this methodology, Lock and Garnsworthy (2003) studied the seasonal variation in the activity of this enzyme and Peterson et al. (2002) showed individual animal differences in $\Delta^{9}$-desaturase activity.

Studying the genetics of the nutritional quality of milk requires a large amount of data. Many previous studies have used chromatographic analyses to estimate the fatty acid content in milk fat (e.g., Bobe et al., 1994; DePeters et al., 1995). This method is efficient (e.g., Dorey et al., 1988; Collomb and Bühler, 2000) but requires a lengthy analysis, expensive reagents, and highly skilled staff. Therefore, these studies are generally restricted in the number of animals and samples available (e.g., 234 cows for Bobe et al., 1994; 90 cows for DePeters et al., 1995). Mid-infrared (MIR) spectrometry is a faster method of estimating the different components of milk (up to 500 samples/h; Foss, 2005). This technology is currently integrated into milk recording to measure different components such as the percentage of fat and protein in milk. Unfortunately, it is used only for major components because adapted calibration equations are not available. A recent study by Soyeurt et al. (2006) provided the first calibration equations for estimating the contents of different fatty acids in milk.

Similar to its current use in routine milk recording, MIR spectrometry is an interesting alternative for providing indications of the fatty acid content in cow's milk for the dairy sector (Soyeurt et al., 2006). The predicted concentrations of fatty acids based on MIR spectrometry could be used as indicator traits for the actual underlying fatty acid concentrations. The objective of this project was to study predicted results for the fatty acid contents in dairy cattle milk and for $\Delta^{9}$-desaturase activity based on MIR spectrometry of milk and milk fat.

\section{MATERIALS AND METHODS}

\section{Animal Population and Milk Samples}

Six hundred milk samples were collected from 275 cows in 7 herds. The herds were selected using several criteria: their participation in Walloon milk recording, the observed variation in the percentage of milk fat, and the number of different breeds in the herds. Twenty-four-hour milk samples, representing $50 \%$ of the morning milk and $50 \%$ of the evening milk, were taken from all cows in each reference herd during the routine milk recording.
Samples were collected from April to June 2005 from 6 breeds: Dual Purpose Belgian Blue (DPB), HolsteinFriesian (HOL), Jersey (JER), Montbeliarde (MON), Normande (NOR), and non-Holstein Meuse-Rhine-Yssel type Red and White breeds (RED). This time period covered no grazing feeding for the samples taken in April, partial grazing feeding for the samples taken in May, and total grazing feeding for the samples taken in June. Because of technical issues, the number of test days was not constant for all herds. Also, some cows were dried off or calved during this experiment. Breed composition was determined out of the known pedigrees of the animals. A certain percentage of genes were of unknown origin. Therefore, in the analysis, these genes were treated as though provided by another breed. Only 2 NOR cows were included in the animal population (Table 1). Also, because of technical problems with spectra file acquisition, only limited fatty acid data were obtained from NOR, and we decided that these data were insufficient to study the variation in fatty acid content for this breed. The presence of the HOL genes (20 to $83.33 \%$ of average breed composition of a given herd) on all farms allowed us to study them at the same time and theoretically to separate environmental, breed, and animal effects (Table 1).

\section{Predicted Concentrations of Fatty Acid in Milk and Milk Fat}

All milk samples were analyzed by an MIR spectrometer (Foss MilkoScan FT6000; Foss, Hillerød, Denmark), an instrument that also provided the standard milk recording analyses (Foss, 2006). The calibration equations used were those obtained by Soyeurt et al. (2006). We considered only those that were reasonably reliable, with cross-validation coefficients of determination above or equal to 0.60 . The calibration equations enabled prediction of 12:0, 14:0, SAT in milk fat ( $\mathrm{g} / 100$ $\mathrm{g}$ of fat), 12:0, 14:0, 16:0, 16:1 cis-9, 18:0, 18:1, 18:2 cis9,cis-12, SAT, and MONO in milk (g/dL of milk).

\section{Differences in Fatty Acid Profiles}

Predicted contents for the different fatty acids in milk or milk fat were analyzed using the following singletrait mixed model:

$$
\mathbf{y}=\mathbf{X} \boldsymbol{\beta}+\mathbf{Z u}+\mathbf{e}
$$

where $\mathbf{y}$ is the vector of observations (fat, fatty acid content in milk or milk fat); $\boldsymbol{\beta}$ is the vector of fixed effects (herd $\times$ test day, parity number, stage of lactation, regressions on breed composition because many animals were crossbred; when the fatty acid content in 
Table 1. Average breed composition of studied herds (in \%) ${ }^{1}$

\begin{tabular}{|c|c|c|c|c|c|c|c|}
\hline \multirow[b]{2}{*}{ Breed } & \multicolumn{7}{|c|}{ Herd } \\
\hline & 1 & 2 & 3 & 4 & 5 & 6 & 7 \\
\hline DPB & & 43.53 & 17.95 & & & & \\
\hline RED & 30.62 & & 25.64 & 14.57 & & 5.61 & 12.92 \\
\hline HOL & 62.66 & 22.06 & 51.28 & 41.60 & 20.00 & 79.04 & 83.33 \\
\hline JER & & & & & 71.96 & & \\
\hline MON & & & & 41.70 & & & \\
\hline NOR & & & 5.13 & & & & \\
\hline Unknown origin & 6.72 & 34.41 & & 2.13 & 8.04 & 15.35 & 3.75 \\
\hline
\end{tabular}

${ }^{1} \mathrm{DPB}=$ Dual Purpose Belgian Blue breed; RED = non-Holstein Red and White breed; HOL = HolsteinFriesian breed; JER = Jersey breed; MON = Montbeliarde breed; NOR = Normande breed.

milk fat was analyzed, a regression for the milk fat percentage was added to prevent bias attributable to variation in the fat percentage in milk); $\mathbf{u}$ is the vector of random repetition on animal effect; $\mathbf{X}$ and $\mathbf{Z}$ are incidence matrices; and $\mathbf{e}$ is the vector of random residual effects.

Animals were considered unrelated because tests using the relationship matrix and separated genetic and permanent environmental effects did not converge. Computations were done with PROC MIXED (SAS Institute, 1999), and variance components were estimated by REML. Results for regression on breed composition were reported in comparison with the reference HOL breed. To allow an optimal comparison among studied breeds and traits, results are reported in standardized values. The standard deviations used were based on the total variances given in Tables $2,3,4$, and 5 .

Animal repeatability was estimated from the ratio of animal variance to total variance. Overall individual effects were estimated from the sum of the breed and the specific animal effects. These individual effects should be considered as corrected phenotypic values for the different cows. Finally, the phenotypic correlations among traits were also estimated based on the correlations among these individual effects.

As mentioned, $\Delta^{9}$-desaturase activity is important for explaining the variation in fatty acid composition because it has been implicated in the production of the majority of MONO and all CLA present in milk. With the MIR predictions for $14: 1 \mathrm{cis}-9,16: 1 \mathrm{cis}-9,18: 1,14: 0$, $16: 0$, and 18:0, the product-to-substrate ratios were computed and analyzed with the same mixed model as that envisaged for the study of fatty acids in milk.

\section{RESULTS AND DISCUSSION}

\section{Differences in Fatty Acid Content in Milk and Milk Fat Among Breeds}

Table 2 shows the mean and standard deviation for each milk fat component estimated for the 600 milk samples. Tables 3, 4, and 5 report differences in the fatty acid content of milk, fatty acid content of fat, and $\Delta^{9}$-desaturase activity among breeds, respectively. In these 3 tables, differences are presented with their associated $P$-values, which allowed us to test the overall significance level of breed differences and the significance of comparisons between a given breed and HOL. Because the differences may not be easy to visualize, Figures 1, 2, and 3 also show graphical representations of differences among the studied breeds for the same traits.

Even though the best indicator for $\Delta^{9}$-desaturase activity is theoretically the ratio of $14: 1$ cis-9 to $14: 0$, because 14:1 cis-9 is derived only through desaturation (Lock and Garnsworthy, 2003), the best predictor of $\Delta^{9}$ activity for this study was the ratio of $16: 1 \mathrm{cis}-9$ to $16: 0$. This is because of the low value for the cross-validation coefficient of determination obtained from the calibration equation that predicted the 14:1 cis-9 concentration in milk. The ratio of $16: 1 \mathrm{cis}-9$ to $16: 0$ would therefore be preferred (Soyeurt et al., 2006). As explained before, because $\Delta^{9}$-desaturase has been implicated in the production of fatty acids, its activity was studied, because it might partially explain the observed differences in the fatty acid profiles of milk fat.

Globally, the effect of breed was often significant ( $P$ $<0.05$ ). Tables 3,4 , and 5 show generally low $P$-values for every trait studied except for $16: 1$ cis-9 $(P=0.074)$, 18:1 $(P=0.099)$ in milk, SAT in fat $(P=0.334)$, and the ratios of $18: 1$ to $18: 0(P=0.092)$ and $14: 1 \mathrm{cis}-9$ to $14: 0(P=0.319)$. In particular, Table 5 shows that breed effect had a significant impact on $\Delta^{9}$-desaturase activity for the $16: 1 \mathrm{cis}-9$ to $16: 0$ ratio $(P=0.044)$, the best predictor used in our study. Kelsey et al. (2003) also showed that $\Delta^{9}$-desaturase activity differed between breeds (HOL and Brown Swiss), but this effect was minor. This minor impact might be explained by the low number of breeds studied by Kelsey et al. (2003).

As shown in Table 3, JER showed the greatest difference in milk fatty acid content compared with HOL. 
Table 2. Mean, standard deviation, individual standardized variation, repeatability, and total variance estimate for milk and milk fat components $(\mathrm{n}=600)^{1}$

\begin{tabular}{|c|c|c|c|c|c|c|c|c|c|c|c|c|}
\hline \multirow[b]{2}{*}{ Milk component } & \multicolumn{6}{|c|}{ Milk (g/dL of milk) } & \multicolumn{6}{|c|}{ Milk fat ( $\mathrm{g} / 100 \mathrm{~g}$ of fat) } \\
\hline & Mean & SD & Min & Max & $\begin{array}{l}\text { Rep } \\
(\%)\end{array}$ & $\begin{array}{c}\sigma^{2} \\
(\mathrm{~g} / \mathrm{dL} \text { of } \\
\text { milk })^{2}\end{array}$ & Mean & SD & Min & Max & $\begin{array}{l}\text { Rep } \\
(\%)\end{array}$ & $\begin{array}{c}\sigma^{2} \\
(\mathrm{~g} / 100 \mathrm{~g} \\
\text { of } \text { fat })^{2}\end{array}$ \\
\hline Fat & 4.30 & 0.90 & -1.34 & 2.69 & 47.83 & 0.36 & & & & & & \\
\hline SAT & 2.88 & 0.67 & -1.43 & 3.03 & 55.99 & 0.19 & 66.44 & 4.06 & -2.38 & 1.68 & 54.64 & 7.25 \\
\hline MONO & 1.27 & 0.32 & -1.44 & 2.79 & 44.48 & 0.056 & & & & & & \\
\hline $12: 0$ & 0.12 & 0.03 & -1.88 & 3.29 & 60.91 & 0.00058 & 2.84 & 0.47 & -2.25 & 2.40 & 57.69 & 0.15 \\
\hline $16: 1$ cis -9 & 0.05 & 0.02 & -1.49 & 2.61 & 41.33 & 0.00014 & & & & & & \\
\hline $18: 0$ & 0.52 & 0.15 & -1.23 & 2.63 & 49.63 & 0.0099 & & & & & & \\
\hline $18: 1$ & 1.16 & 0.31 & -1.45 & 2.76 & 43.91 & 0.046 & & & & & & \\
\hline $18: 2$ cis $-9, c i s-12$ & 0.08 & 0.02 & -1.34 & 3.40 & 51.78 & 0.00016 & & & & & & \\
\hline
\end{tabular}

${ }^{1}$ Min = Minimum estimated individual variation for each studied component in milk and milk fat; Max = maximum estimated individual variation for each studied component in milk; $\operatorname{Rep}=$ repeatability; $\sigma^{2}=$ total variance; $\mathrm{SAT}=$ saturated fatty acids; MONO = monounsaturated fatty acids.

The differences between JER and HOL in the fatty acid profiles of milk were generally significant except for 16:1 cis-9 $(P=0.230)$. In addition, the JER milk contained a SAT fraction of higher nutritional quality than that in HOL milk (Figure 1), a result which has previously been mentioned by Palmquist and Beaulieu (1992), DePeters et al. (1995), Hermansen and Lund (1990), and Beaulieu and Palmquist (1995). Although the milk of JER cows contained a higher percentage of fat than that of HOL cows (Figure 1), there were no significant differences between these 2 breeds concerning the proportion of SAT in milk fat after correcting for fat percentage differences (Table $4 ; P=0.460$ ). This observation might be explained by the similar $\Delta^{9}$-desaturase activity observed for these 2 breeds (Table 5 and Figure 3 ). The SAT fraction in JER milk fat was slightly higher, and the unsaturated fraction was therefore a bit lower, than in HOL (Figure 2), but the difference was not significant $(P=0.460)$. This result was in agreement with Palmquist and Beaulieu (1992), who indicated that 18:1 was $15 \%$ lower in JER than in HOL milk fat, as well as with DePeters et al. (1995) and Beaulieu and Palmquist (1995).

With regard to DPB, Tables 3 and 4 show that the fatty acid profiles linked to milk or fat between this breed and HOL were slightly different; however, except for 16:0 $(P=0.033)$, these differences were not significant. Although the DPB had the lowest concentrations of milk fat, SAT, and MONO in milk, the concentrations of $18: 1$ and 18:2 cis-9,cis-12 observed for this breed were not the lowest across the studied breeds (Figure 1). This confirms an unsaturated fraction in DPB milk fat that was more important than in the milk fat of the other studied breeds. This is supported by the fact that the milk fat of DPB contained the lowest proportion of SAT (Figure 2). One has to consider these results in the light of a correction for milk fat percentage; therefore, the SAT contents were comparable even though the fat per-

Table 3. Standardized differences in fatty acid content in milk ( $\mathrm{g} / \mathrm{dL}$ of milk) between studied breeds and Holsteins, and $P$-values for differences among all breeds (in parentheses) ${ }^{1}$

\begin{tabular}{|c|c|c|c|c|c|c|c|c|c|c|}
\hline Breed & \multicolumn{10}{|c|}{ Milk fat and fatty acids (g/dL of milk) } \\
\hline RED & $\begin{array}{c}-0.12 \\
(P=0.625)\end{array}$ & $\begin{array}{c}-0.01 \\
(P=0.982)\end{array}$ & $\begin{array}{c}-0.40 \\
(P=0.116)\end{array}$ & $\begin{array}{c}0.32 \\
(P=0.226)\end{array}$ & $\begin{aligned} & 0.13 \\
&(P=0.627)\end{aligned}$ & $\begin{array}{c}-0.15 \\
(P=0.549)\end{array}$ & $\begin{array}{c}-0.52 \\
(P=0.038)\end{array}$ & $\begin{array}{c}-0.08 \\
(P=0.745)\end{array}$ & $\begin{array}{c}-0.31 \\
(P=0.214)\end{array}$ & $\begin{array}{c}-0.23 \\
(P=0.370)\end{array}$ \\
\hline JER & $\begin{array}{c}1.46 \\
(P<0.001)\end{array}$ & $\begin{array}{c}1.60 \\
(P<0.001)\end{array}$ & $\begin{array}{c}\quad 0.95 \\
(P=0.009)\end{array}$ & $\begin{array}{c}1.37 \\
(P<0.001)\end{array}$ & $\begin{array}{c}1.40 \\
(P<0.001)\end{array}$ & $\left(P=\begin{array}{l}1.16 \\
0.002)\end{array}\right.$ & $\begin{array}{c}0.43 \\
(P=0.230)\end{array}$ & $\begin{array}{c}1.45 \\
(P<0.001)\end{array}$ & $\begin{aligned} & 0.88 \\
(P= & 0.016)\end{aligned}$ & $\begin{aligned} & 1.25 \\
(P= & 0.001)\end{aligned}$ \\
\hline
\end{tabular}

${ }^{1} \mathrm{SAT}=$ Saturated fatty acids; MONO = monounsaturated fatty acids; DPB = Dual Purpose Belgian Blue; RED = Red and White; MON = Montbeliarde; JER = Jersey. 
Table 4. Standardized differences in fatty acid content in fat $(\mathrm{g} / 100$ $\mathrm{g}$ of fat) between studied breeds and Holsteins, and $P$-values for differences among all breeds (in parentheses) ${ }^{1}$

\begin{tabular}{lccc}
\hline & \multicolumn{3}{c}{ Saturated milk fat and fatty acids $(\mathrm{g} / 100 \mathrm{~g}$ of fat $)$} \\
\cline { 2 - 4 } Breed & SAT & $\begin{array}{l}12: 0 \\
(P=0.334)\end{array}$ & $\begin{array}{l}14: 0 \\
(P=0.032)\end{array}$ \\
\hline DPB & -0.22 & 0.01 & 0.04 \\
& $(P=0.495)$ & $(P=0.976)$ & $(P=0.912)$ \\
RED & 0.37 & 0.15 & 0.19 \\
MON & $(P=0.157)$ & $(P=0.569)$ & $(P=0.452)$ \\
& $(P=0.39$ & 1.08 & 0.97 \\
JER & $0.257)$ & $(P=0.002)$ & $(P=0.005)$ \\
& $(P=0.460)$ & $(P=0.052)$ & $(P=0.57$ \\
\end{tabular}

${ }^{1} \mathrm{SAT}=$ Saturated fatty acids $; \mathrm{DPB}=$ Dual Purpose Belgian Blue; RED = Red and White; MON = Montbeliarde; JER = Jersey.

centages were different. These observations might be explained by the activity of $\Delta^{9}$-desaturase for this breed (Figure 3). Indeed, for all 3 ratios, DPB had higher $\Delta^{9}$ desaturase activity compared with all the other breeds. Even though these results were not significant, they may assist in understanding the findings from this study (Table 5).

Similarly, the milk fat of RED and MON contained the highest proportion of SAT (Figure 2). In particular, the MON milk fat contained a significantly higher proportion of 12:0 and 14:0 than the milk fat from HOL cows (Table 4; respectively, $P=0.02$ and $P=0.05$ ). This might be explained by a significantly lower $\Delta^{9}$ activity for these 2 breeds compared with HOL (Figure 3). However, Lawless et al. (1999) indicated that the MON milk fat had a low fraction of SAT and that the concentrations of $12: 0$ and 14:0 were equal to those observed in HOL milk fat. This divergence might be explained by the fact that the results obtained by Lawless et al. (1999) were raw phenotypic values and therefore might

Table 5. Standardized differences in $\Delta^{9}$-desaturase activity between the studied breeds and Holsteins, and $P$-values for differences among all breeds (in parentheses) ${ }^{1}$

\begin{tabular}{lccc}
\hline & \multicolumn{3}{c}{$\Delta^{9}$-desaturase activity } \\
\cline { 2 - 4 } Breed & $\begin{array}{l}18: 1 \text { to } 18: 0 \text { ratio } \\
(P=0.092)\end{array}$ & $\begin{array}{l}16: 1 \text { to } 16: 0 \text { ratio } \\
(P=0.044)\end{array}$ & $\begin{array}{l}14: 1 \text { to } 14: 0 \text { ratio } \\
(P=0.319)\end{array}$ \\
\hline DPB & 0.30 & 0.06 & 0.20 \\
& $(P=0.345)$ & $(P=0.853)$ & $(P=0.518)$ \\
RED & -0.38 & -0.60 & -0.21 \\
MON & $(P=0.136)$ & $(P=0.018)$ & $(P=0.411)$ \\
& -0.72 & -0.67 & -0.62 \\
JER & $(P=0.353)$ & $(P=0.047)$ & $(P=0.064)$ \\
& $(P=0.01$ & -0.17 & -0.06 \\
\end{tabular}

${ }^{1} \mathrm{DPB}=$ Dual Purpose Belgian Blue; RED = Red and White; $\mathrm{MON}=$ Montbeliarde; JER = Jersey. have been much more influenced by other factors, for example, by feeding practices and stage of lactation. In the current study, breeds were compared on the same farms, and variation among individual animals was corrected for different fixed effects.

\section{Differences in Fatty Acid Profiles of Milk and Milk Fat Within Breeds}

For all the studied components (proportions of SAT, 12:0, and so on in milk and in milk fat), the estimated values for repeatability were high (Table 2 ) and ranged from to 41.33 to $60.91 \%$. This could suggest a reasonably moderate heritability for each studied component, similar to what is known for fat (Interbull, 2005). The first study, reported by Edwards et al. (1973) for estimating the heritability of each fatty acid, indicated extremely high heritabilities, between 0.64 for $12: 0$ and 0.98 for 12:1 and 14:1. These values can be considered as high overestimations because a biased hypothesis was used to compute the heritability. The environmental variance was estimated from the variance component within monozygous pairs. The variance components within dizygous pairs represented the environmental variance and half the genetic variance. In spite of these overestimated values, this study was the first to show high heritability for each fatty acid in milk fat. The repeatability of milk fat components was previously shown by Karijord et al. (1982). For the same contents, the values obtained by Karijord et al. (1982) ranged from 0.10 to 0.33 . The differences in values found between these 2 studies might be explained by the data analyzed and the models used. The fixed effects used by Karijord et al. (1982) were only the effect of stage of lactation and the effect of month. The heritabilities estimated by Bobe et al. (1994) were 0.18 for $18: 0$ and 0.39 for 14:0. A similar conclusion was drawn by Renner and Kosmack (1974a), with 0.26 for short-chain, 0.20 for medium-chain, and 0.30 for long-chain fatty acids. Because the heritability is also a part of the repeatability, our results suggest that the heritability of each fatty acid could be reasonably high.

For $\Delta^{9}$-desaturase, the estimated repeatability for the ratios of $14: 1 \mathrm{cis}-9$ to $14: 0,16: 1 \mathrm{cis}-9$ to $16: 0$, and 18:1 to $18: 0$ were, respectively, $43.12,41.78$, and $45.79 \%$. These values might also suggest a reasonably moderate heritability. Lock and Garnsworthy (2003) previously reported the variation in $\Delta^{9}$ activity within breeds. Similarly, Royal and Garnsworthy (2005) reported heritability values of 0.30 and 0.19 for the ratios of $14: 1$ to $(14: 0+14: 1)$ and $18: 1$ to $(18: 0+18: 1)$, respectively. Lock et al. (2005) and Peterson et al. (2002) confirmed that nutritional and individual variation in 


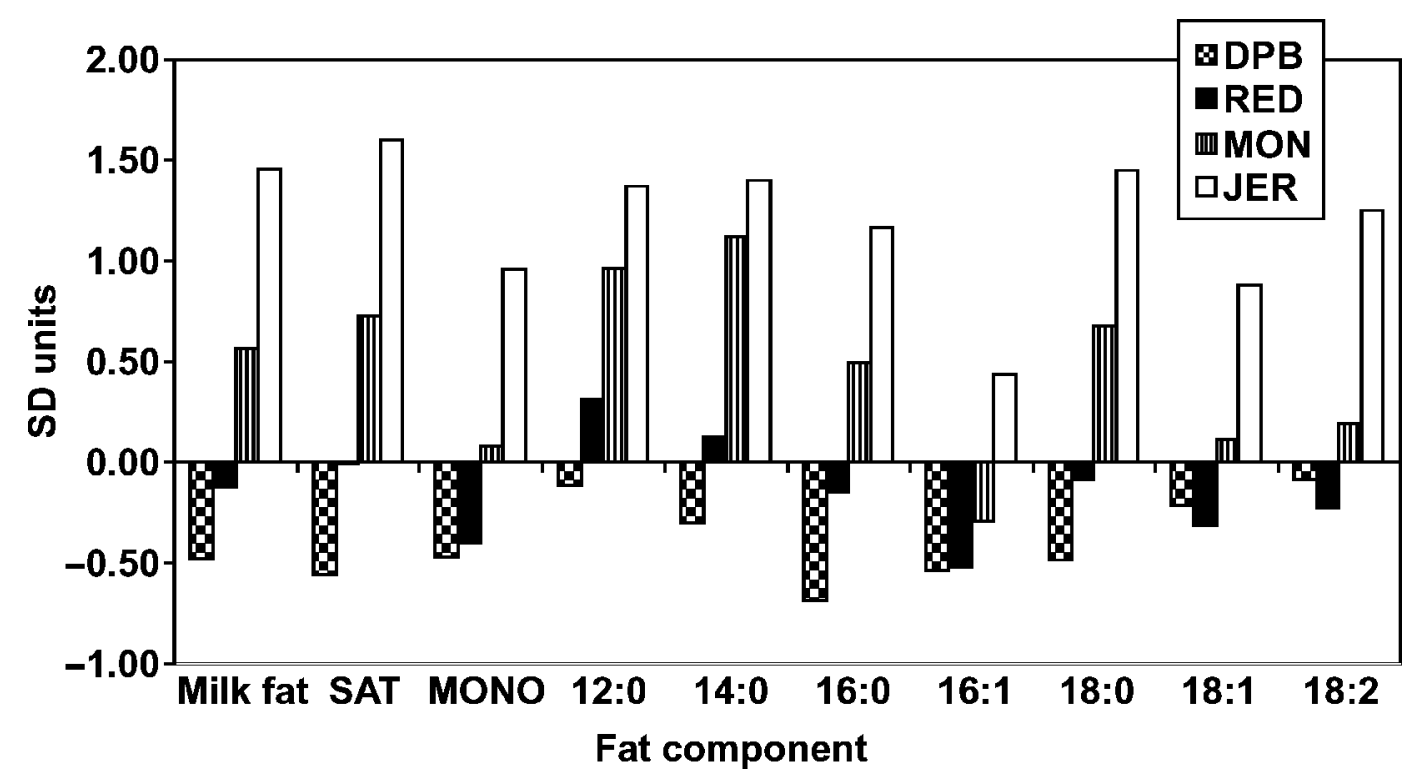

Figure 1. Differences in fat components $(18: 2=18: 2$ cis-9, cis-12; MONO = monounsaturated fatty acids; SAT = saturated fatty acids $)$ of milk [standard deviation (SD) units] for 4 breeds (DPB = Dual Purpose Belgian Blue; JER = Jersey; MON = Montbeliarde; RED = Red and White) compared with Holsteins.

$\Delta^{9}$-desaturase activity were the major factors contributing to the concentration of rumenic acid in milk.

\section{Individual Variation}

For the concentrations of fatty acids in milk, the mean scale of variation attributable to individual effects ranged from -1.30 to +2.80 standard deviation units, and the mean scale of variation attributable to breed effects ranged from -0.40 to +1.20 standard deviation units (Table 2). The range of individual values was higher than the variation across selected breeds. The

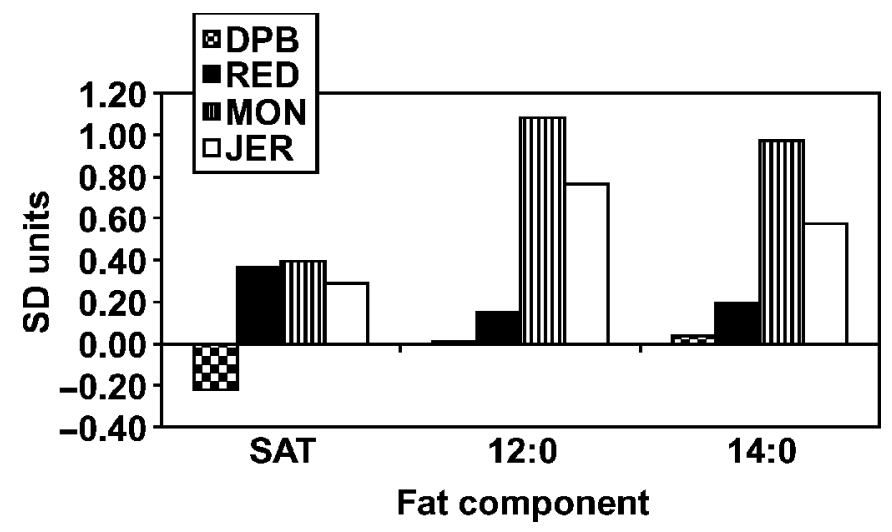

Figure 2. Differences in fat components (SAT = saturated fatty acids) of milk fat [standard deviation (SD) units] for 4 breeds (DPB = Dual Purpose Belgian Blue; JER = Jersey; MON = Montbeliarde; RED = Red and White) compared with Holsteins. same conclusion applied to the concentrations of fatty acids in milk fat (Table 2).

\section{Correlations}

Table 6 shows the phenotypic correlations between the studied components in milk. The values shown are Pearson correlation coefficients estimated among the individual effects. In general, high positive correlations were observed, with several exceptions. The correlations between $16: 1 \mathrm{cis}-9$ and $12: 0$ and between $16: 1 \mathrm{cis}$ 9 and 14:0 were low and negative. Low correlations between MONO and 12:0, MONO and 14:0, 14:0 and 18:1, and 14:0 and 18:2 cis-9,cis-12 were also observed.

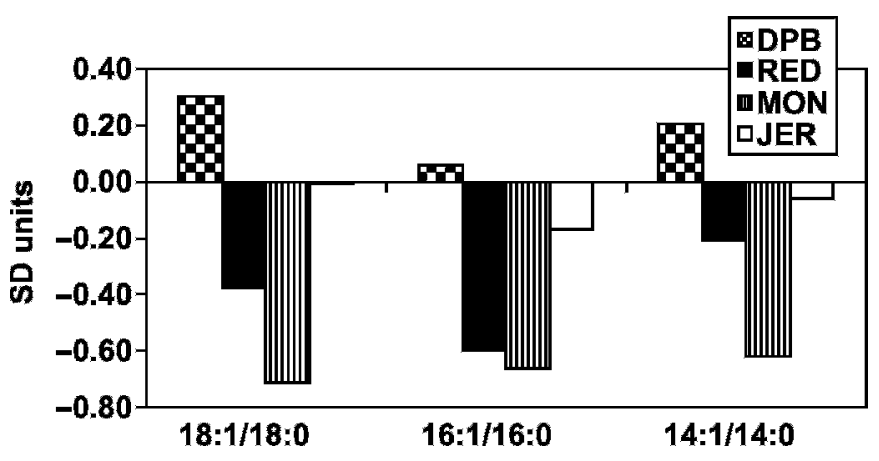

Figure 3. Differences in activity of $\Delta^{9}$-desaturase [standard deviation (SD) units] for 4 breeds (DPB = Dual Purpose Belgian Blue; JER = Jersey; $\mathrm{MON}=$ Montbeliarde $; \mathrm{RED}=$ Red and White) compared with Holsteins. 
Table 6. Phenotypic correlations between studied components of milk estimated from individual effects ${ }^{1}$

\begin{tabular}{llllllllll}
\hline Component & SAT & MONO & $12: 0$ & $14: 0$ & $16: 0$ & $16: 1$ & $18: 0$ & $18: 1$ & $18: 2$ \\
\hline Milk fat & 0.95 & 0.85 & 0.68 & 0.77 & 0.94 & 0.58 & 0.98 & 0.80 & 0.82 \\
SAT & & 0.70 & 0.83 & 0.89 & 0.94 & 0.39 & 0.97 & 0.60 & 0.70 \\
MONO & & & 0.24 & 0.36 & 0.79 & 0.91 & 0.81 & 0.96 & 0.89 \\
12:0 & & & 0.95 & 0.67 & -0.12 & 0.72 & 0.16 & 0.89 \\
$14: 0$ & & & & 0.75 & -0.01 & 0.80 & 0.31 & 0.39 \\
$16: 0$ & & & & & 0.54 & 0.95 & 0.68 & 0.72 \\
$16: 1$ & & & & & & 0.52 & 0.87 & 0.75 \\
$18: 0$ & & & & & & & & 0.75 & 0.79 \\
$18: 1$ & & & & & & & & & \\
\hline
\end{tabular}

${ }^{1} \mathrm{SAT}=$ Saturated fatty acids $; \mathrm{MONO}=$ monounsaturated fatty acids; $16: 1=16: 1 \mathrm{cis}-9 ; 18: 2=18: 2 \mathrm{cis}$ $9, c i s-12$.

These findings are important because they suggest that animal selection based on the fatty acid profile might be possible. Bobe et al. (1994) obtained a phenotypic correlation of 0.69 between 14:0 and 18:0. This value is in agreement with the value obtained in this study (0.80). Also, Karijord et al. (1982) observed lower correlations between milk components and fat than the values obtained in this study. This might be explained by differences in the data and the models used. In addition, Renner and Kosmack (1974b) obtained high genetic correlations, with fat yield equal to 1.00 for short-chain, 0.48 for medium-chain, and -0.98 for long-chain POLY. The same conclusion applies to the concentrations of fatty acids in milk fat. Indeed, high phenotypic correlations (results not shown) were found in the current study for the concentrations of fatty acids in milk fat.

\section{CONCLUSIONS}

This study revealed differences in the fatty acid content of milk across the studied breeds, which suggests the possibility of obtaining milk products with improved nutritional quality by choosing the right breed. Considerable variation within breed was also found. This might suggest a moderate heritability for each component in the fatty acid profile. The high values estimated by this study for individual variation suggest the existence of genetic variability. Finally, some low phenotypic correlations were estimated using individual effects.

Although the aforementioned results are interesting, they also suggest the need for further research, especially into the estimation of genetic parameters for milk fat components. An objective of future research should be to confirm the possibility of a differentiated quantitative selection of fatty acids to modify the nutritional quality of milk and milk fat. The final objective should be to produce healthier milk products based on genetic selection for modified global fatty acid profiles.

\section{ACKNOWLEDGMENTS}

Hélène Soyeurt acknowledges the support of the FRIA through a grant scholarship. Coraline Croquet (research fellow) and Nicolas Gengler (research associate) of the National Fund for Scientific Research (Brussels, Belgium) acknowledge its support. Additional support was provided through Grant 2.4507.02F (2) of the National Fund for Scientific Research. The authors gratefully acknowledge the support of the Walloon Breeding Association (AWE) and the Walloon Milkcomite. The authors also acknowledge the partial financial support of this project by the Walloon Regional Ministry of Agriculture (Ministère de la Région Wallonne, Direction Générale de l'Agriculture).

\section{REFERENCES}

Beaulieu, A. D., and D. L. Palmquist. 1995. Differential effects of high fat diets on fatty acid composition in milk of Jersey and Holstein cows. J. Dairy Sci. 78:1336-1344.

Bobe, G., A. E. Freeman, and G. L. Lindberg. 1994. New selection criteria to alter milk composition. DSL-58. Iowa State University. http://www.extension.iastate.edu/Pages/dairy/report95/products/ dsl-58.pdf Accessed Nov. 3, 2005.

Chilliard, Y., A. Ferlay, R. M. Mansbridge, and M. Doreau. 2000. Ruminant milk fat plasticity: Nutritional control of saturated, polyunsaturated, trans and conjugated fatty acids. Ann. Zootechnol. 49:181-205.

Collomb, M., and T. Bühler. 2000. Analyse de la composition en acides gras de la graisse de lait. Mitt. Lebensm. Hyg. 91:306-332.

Demeyer, D., and M. Doreau. 1999. Pourquoi et comment modifier les lipides du lait et de la viande bovine. Cah. Nutr. Diet. 34:301-308.

DePeters, E. J., J. F. Medrano, and B. A. Reed. 1995. Fatty acid composition of milk fat from three breeds of dairy cattle. Can. J. Anim. Sci. 75:267-269.

Dorey, F., D. Brodin, J.-F. Le Querler, and S. Kudzal-Savoie. 1988. Analyse des acides gras du beurre par chromatographie en phase gazeuse couplée avec la spectrométrie de masse. IAA (June):437-441.

Edwards, R. A., J. W. B. King, and I. M. Yousef. 1973. A note on the genetic variation in the fatty acid composition of cow milk. Anim. Prod. 16:307-310.

Foss. 2006. MilkoScan ${ }^{\mathrm{TM}}$ FT6000. http://www.foss.dk/Solutions/ ProductsDirect/MilkoScanFT6000.aspx Accessed Sep. 18, 2006.

Grummer, R. R. 1991. Effect of feed on the composition of milk fat. J. Dairy Sci. 74:3244-3257. 
Hayes, K. C., and D. R. Khosla. 1992. Dietary fatty acid thresholds and cholesterolemia. FASEB J. 6:2600-2607.

Hermansen, J. E., and P. Lund. 1990. Fatty acid composition and milk quality related to feeding Ca-saponified palm acid oil to different breeds of dairy cows. J. Dairy Res. 57:23-31.

Hu, F. B., M. J. Stampfer, J. E. Manson, A. Ascherio, G. A. Colditz, F. E. Speizer, C. H. Hennekens, and W. C. Willet. 1999. Dietary saturated fat and their food sources in relation to the risk of coronary heart disease in women. Am. J. Clin. Nutr. 70:10011008.

Interbull. 2005. Genetic evaluations: Production. http://wwwinterbull.slu.se/eval/framesida-prod.htm Accessed Apr. 5, 2005.

Karijord, Ø., N. Standal, and O. Syrstad. 1982. Sources of variation in composition of milk fat. Z. Tierzüchtg. Züchtgsbiol. 99:81-93.

Kelsey, J. A., B. A. Corl, R. J. Collier, and D. E. Bauman. 2003. The effect of breed, parity and stage of lactation on conjugated linoleic acid (CLA) in milk fat from dairy cows. J. Dairy Sci. 86:2588-2597.

Lawless, F., C. Stanton, P. L'Escop, R. Devery, P. Dillon, and J. J. Murphy. 1999. Influence of breed on bovine milk cis-9,trans-11conjugated linoleic acid content. Livest. Prod. Sci. 62:43-49.

Lock, A. L., D. E. Bauman, and P. C. Garnsworthy. 2005. Short communication: Effect of production variables on the cis-9,trans11 conjugated linoleic acid content of cows' milk. J. Dairy Sci. 88:2714-2717.

Lock, A. L., and P. C. Garnsworthy. 2003. Seasonal variation in milk conjugated linoleic acid and $\Delta 9$-desaturase activity in dairy cows. Livest. Prod. Sci. 79:47-59.

Palmquist, D. L., and A. D. Beaulieu. 1992. Differences between Jersey and Holstein cows in milk fat composition. J. Dairy Sci. 75(Suppl. 1):292. (Abstr.)
Palmquist, D. L., A. D. Beaulieu, and D. M. Barbano. 1993. ADSA foundation symposium: Milk fat synthesis and modification, feed and animal factors influencing milk fat composition. J. Dairy Sci. $76: 1753-1771$.

Pascal, G. 1996. Les apports quotidiens recommandés en lipides et en acides gras. OCL 3:205-210.

Peterson, D. G., J. A. Kelsey, and D. E. Bauman. 2002. Analysis of variation in cis-9,trans-11 conjugated linoleic acid (CLA) in milk fat of dairy cows. J. Dairy Sci. 85:2164-2172.

Renner, E., and U. Kosmack. 1974a. Genetische Aspekte zur Fettsäurenzusammensetzung des Milchfettes. 2. Fettsäurenmuster der Milch von Nachkommenpopulationen. Zuechtungskunde. 46:217-226.

Renner, E., and U. Kosmack. 1974b. Genetische Aspekte zur Fettsäurenzusammensetzung des Milchfettes. 2. Genetische Korrelationen zum Fettgehalt und zur Fettleistung. Zuechtungskunde. 46:257-264.

Royal, M. D., and P. C. Garnsworthy. 2005. Estimation of genetic variation in $\Delta 9$-desaturase enzyme activity in dairy cows. Page 52 in Proc. Br. Soc. Anim. Sci., York, UK. Br. Soc. Anim. Sci., Penicuik, UK.

SAS Institute. 1999. SAS/STAT User's Guide: Version 8. SAS Institute, Inc., Cary, NC.

Simopoulos, A. P. 2003. Importance of ratio of omega-6/omega-3, essential fatty acids: Evolutionary aspects. World Rev. Nutr. Diet. 92:1-22.

Soyeurt, H., P. Dardenne, F. Dehareng, G. Lognay, D. Veselko, M. Marlier, C. Bertozzi, P. Mayeres, and N. Gengler. 2006. Estimating fatty acid content in cow milk using mid-infrared spectrometry. J. Dairy Sci. 89:3690-3695. 